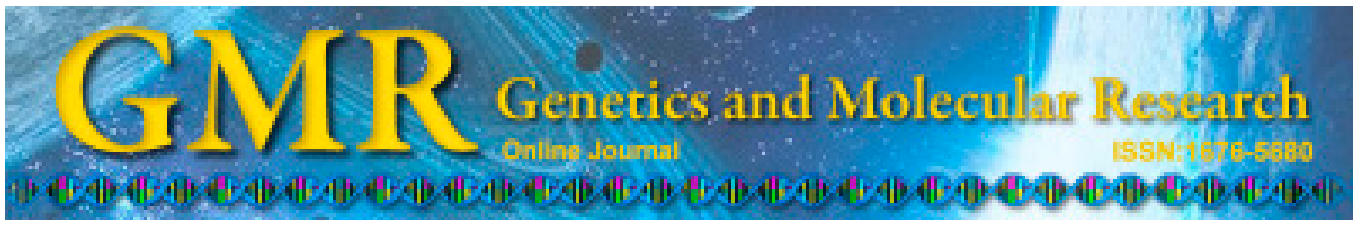

\title{
Impact of caffeine on $\beta$ cell proliferation and apoptosis under the influence of palmitic acid
}

\author{
L. Chen, M. Yu, T. Shen, J. Xia and B.L. Xu \\ Department of Endocrinology, Putuo Hospital, \\ Shanghai University of Traditional Chinese Medicine, Shanghai, China \\ Corresponding author: M. Yu \\ E-mail: yumin_1zz@yeah.net
}

Genet. Mol. Res. 14 (2): 5724-5730 (2015)

Received April 30, 2014

Accepted October 29, 2014

Published May 29, 2015

DOI http://dx.doi.org/10.4238/2015.May.29.4

\begin{abstract}
We examined the influence of caffeine on the proliferation and apoptosis of $\beta$ cells cultured in vitro in the presence of the free fatty acid palmitic acid (PA). Different concentrations of caffeine (1-100 $\mu \mathrm{M})$ and free fatty PA were added to cultured $\beta$ cells. The MTT assay was used to analyze cell proliferative activity; flow cytometry was used to measure apoptosis and calculate the apoptosis rate. Compared with the blank control group, cells cultured with $500 \mu \mathrm{M}$ PA for $24,48,72$, and $96 \mathrm{~h}$ showed inhibition of pancreatic $\beta$ cell proliferative activity. In the 10 and $25 \mu \mathrm{M}$ caffeine groups cultured for 48,72 , and $96 \mathrm{~h}, \beta$ cell proliferative activity was much higher than that in the $500 \mu \mathrm{M}$ PA group. The apoptosis rate in the $500 \mu \mathrm{M}$ PA group was $40.55 \pm 20.33 \%$, which was higher than that in the blank control group. The apoptosis rates in the 10 and $25 \mu \mathrm{M}$ caffeine group and the PA group were 19.12 \pm 10.56 and $20.97 \pm 9.75 \%$, respectively, which was lower than that in the $500 \mu \mathrm{M}$ PA group. At some concentrations, caffeine can improve free fatty PA levels and guide pancreatic $\beta$ cell proliferation inhibition and cell apoptosis.
\end{abstract}

Key words: $\beta$ cell; Caffeine; Flow cytometry; MTT; Palmitic acid 


\section{INTRODUCTION}

Lipotoxicity is an important pathogenesis process that causes pancreatic $\beta$ cell dysfunction and abnormal glucose metabolism. Long-term high-concentration cyclic free fatty acid and high lipid content in cells may negatively affect insulin secretion and insulin action, insulin resistance, and glycoregulation. The complex pathogenesis of pancreatic $\beta$ cell damage caused by glucolipotoxicity is not well understood, and the detailed molecular biological mechanisms require further study. Pancreatic $\beta$ cell damage is an important factor causing altered insulin secretion, may affect the pathogenesis of lipotoxicity, and cause abnormal glucose metabolism. In the blood, palmitate or palmitic acid (PA) exists as a glyceride and as very long-chain saturated fatty acids in blood. Stimulation of long-term high-concentration PA can cause apoptosis of various types of cells (e.g., pancreatic $\beta$ cells), which is typically used to simulate lipotoxicity in studies aiming to prevent and cure diabetes and metabolic disorders involving lipotoxicity (Poitout and Robertson, 2008). A recent study showed that consuming coffee for a long period of time can prevent abnormal glucose metabolism. The most wellknown component of coffee is caffeine, a methylxanthine alkaloid, which plays a role in exciting the central nervous system. However, there have been few studies examining the impact of caffeine on pancreatic $\beta$ cell function and glucose metabolism. To study the impact of caffeine on $\beta$ cell lipotoxicity, we prepared a cell model cultured in vitro with murine insulinoma cells, used PA to guide lipotoxicity, and examined the proliferation and apoptosis of cells in the presence of different concentrations of caffeine.

\section{MATERIAL AND METHODS}

\section{Materials}

The main murine insulinoma cell reagent ( $\beta$-TC-6 cell) was purchased from the Shanghai Institute of Cellular Biology of Chinese Academy of Sciences (Shanghai, China). Caffeine and PA standards were obtained from Shanghai Anpel Biological Technology Co., Ltd. (Shanghai, China). High-glucose Dulbecco's modified Eagle's medium (DMEM) was from Gibco (Grand Island, NY, USA). Qualified fetal bovine serum was from Hyclone (Logan, UT, USA). Dimethylsulfoxide and 3-(4,5-dimethylthiazol-2-yl)-2,5-diphenyltetrazolium bromide (MTT) were from Hai Ding Biological Technology Co., Ltd. (Shanghai, China). Split charging was from Genview (Bi-Tek, Beijing, China). The Annexin V-fluorescein isothiocyanate apoptosis detection reagent kit was purchased from Beijing Biosea Biological Technology Co., Ltd. (Beijing, China).

Experimental equipment included a cell culture shaker (Shel Lab, Cornelius, OR, USA), inverted microscope (Olympus, Tokyo, Japan), MTT microplate reader (East China Electronic Tube Factory, Shanghai, China), 25- and 75- $\mathrm{cm}^{2}$ cell culture bottles, 6-, 24-, and 96well culture plates (Falcon, BD Biosciences, Franklin Lakes, NJ, USA), and flow cytometry apparatus (FACSAria, BD Biosciences).

\section{Methods}

Cells were passaged with $\beta$-TC- 6 cell at a density of $70 \%$. Cells were cultured in a $5 \%$ $\mathrm{CO}_{2}$ shaking incubator in 15\% high-glucose DMEM containing inactivated fetal calf serum (Gibco, $25 \mathrm{mM}$ ), HEPES buffer solution, $100 \mathrm{mM}$ double-resistant penicillin-streptomycin, 
with a 1:3 passage. The medium was changed every 2 days, with 3-5 days to complete 1 passage. Cell fusion ranged from 70 to $80 \%$, and complete medium $+10 \%$ dimethylsulfoxide was used for cryopreservation of the cells.

\section{Preparation of PA with free fatty acid medium}

To prepare the PA medium, $0.01 \mathrm{M} \mathrm{NaOH}$ was used to prepare a 20-mM stock solution, which was then placed in a water bath for $10 \mathrm{~min}$ at $70^{\circ} \mathrm{C}$. Bovine serum albumin without free fatty acid and double-distilled water was used to prepare a $30 \%$ bovine serum albumin solution, which was incubated for $30 \mathrm{~min}$ at $55^{\circ} \mathrm{C}$ in a water bath. Next, 330- and $500-\mu \mathrm{L}$ PA stock solutions were mixed together, and filter-sterilized in DMEM to prepare lipoid medium at a PA concentration of $500 \mu \mathrm{M}, 0.5 \%$ bovine serum albumin, and $\mathrm{pH}$ 7.1-7.2.

$\beta$-TC-6 cells were grown to the logarithmic growth phase, inoculated on a 96-well plate, with 10 groups used: blank group (medium without free fatty acid), PA group (lipoid medium containing $500 \mu \mathrm{M} \mathrm{PA}$ ), 4 groups of PA + caffeine (each group containing fatty medium and 1 , 10,25 , or $100 \mu \mathrm{M}$ caffeine and $500 \mu \mathrm{M} \mathrm{PA}$ ), 4 groups of caffeine (each group with medium containing 1, 10, 25, or $100 \mu \mathrm{M}$ caffeine). Each concentration has 6 wells. A blank medium group was used as a control. All samples were incubated at $37^{\circ} \mathrm{C}$ in a $5 \% \mathrm{CO}_{2}$ cell shaker.

\section{MTT proliferation test}

The 10 groups were cultured for $24 \mathrm{~h}$, and then $20 \mu \mathrm{L} 5 \mathrm{~g} / \mathrm{L}$ MTT was added to each well. After culturing for $4 \mathrm{~h}$ at $37^{\circ} \mathrm{C}$, the medium was removed and $200 \mu \mathrm{L}$ dimethylsulfoxide was added. The cells were kept in the dark and the optical density (OD) was read at $490 \mathrm{~nm}$ using a microplate reader. The OD of the blank control group was subtracted from that of the treatment group to determine cell proliferative activity in the sample. The OD of each group was determined after 48,72 , and $96 \mathrm{~h}$ of culture.

\section{Flow cytometry to measure cell apoptosis}

$\beta$-TC-6 cells were cultured to the logarithmic growth phase, placed on a 96-well plate, with each well containing $1.5 \times 10^{4}$ cells. Cells were cultured for $48 \mathrm{~h}$ with mechanical feeding and 6 ventral orifices in each well. After treatment, the cells were collected into a tube and centrifuged at $1500 \mathrm{~g}$ for $5 \mathrm{~min}$. The supernatant was removed and the cells were washed twice with phosphate-buffered saline. Next, $200 \mu \mathrm{L}$ binding buffer was added to each sample and the cells were resuspended, after which $5 \mu \mathrm{L}$ AnnexinV-fluorescein isothiocyanate was added, mixed gently, and the samples were placed at $2-8^{\circ} \mathrm{C}$ for $15 \mathrm{~min}$ in the dark. After incubation, $10 \mu \mathrm{L}$ propidium iodide was added and the samples were incubated in the same environment for $5 \mathrm{~min}$. A flow cell device was used to measure apoptosis within $1 \mathrm{~h}$.

\section{Statistical analysis}

All measurement data are reported as the average \pm standard deviation. SPSS13.0 was used for statistical analysis (SPSS, Inc., Chicago, IL, USA). Differences were compared among measurement data by analysis of variance. The Dunnett test was used to analyze differences among the blank group, PA + caffeine group, caffeine group, and PA group, as well 
as differences among the PA group, PA + caffeine group, caffeine group, and blank group. $\mathrm{P}<$ 0.05 was considered to indicate a significant difference.

\section{RESULTS}

\section{Influence of PA and different concentrations of caffeine on the proliferation of $\beta$-TC-6 cultured in vitro}

Each group was cultured for $24,48,72$, and $96 \mathrm{~h}$ to measure cell proliferation activity using the MTT assay. Compared with the blank group, the $500 \mu \mathrm{M}$ PA group (PA group) showed clear inhibition of $\beta$-TC- 6 cell proliferation activity at all tested time points. The caffeine + PA group showed MTT cell proliferation activity, while the 10 and $25 \mu \mathrm{M}$ caffeine + PA groups generally showed inhibited proliferation compared to the blank group, but cell proliferation activity was higher than that in the PA group. Compared with the blank group, the caffeine group (only caffeine in medium) showed no differences in cell proliferation activity (Tables 1-4).

\begin{tabular}{|c|c|c|c|c|c|c|c|c|c|c|}
\hline & \multirow{2}{*}{$\frac{\text { Blank group }}{0}$} & \multirow{2}{*}{$\frac{\text { PA group }}{0}$} & \multicolumn{4}{|c|}{$\mathrm{PA}+$ caffeine $(\mu \mathrm{m})$ group } & \multicolumn{4}{|c|}{ Caffeine $(\mu \mathrm{m})$ alone } \\
\hline & & & 1 & 10 & 25 & 100 & 1 & 10 & 25 & 100 \\
\hline OD & $\begin{array}{l}0.208 \pm \\
0.012\end{array}$ & $\begin{array}{l}0.113 \pm \\
0.008^{\dagger}\end{array}$ & $\begin{array}{l}0.132 \pm \\
0.024^{\dagger}\end{array}$ & $\begin{array}{l}0.129 \pm \\
0.029^{\dagger}\end{array}$ & $\begin{array}{l}0.154 \pm \\
0.031\end{array}$ & $\begin{array}{l}0.133 \pm \\
0.042^{\dagger}\end{array}$ & $\begin{array}{l}0.234 \pm \\
0.024 *\end{array}$ & $\begin{array}{l}0.210 \pm \\
0.010^{*}\end{array}$ & $\begin{array}{l}0.134 \pm \\
0.033\end{array}$ & $\begin{array}{l}0.133 \pm \\
0.021\end{array}$ \\
\hline
\end{tabular}

${ }^{\dagger} \mathrm{P}<0.05$ compared with the blank group. $* \mathrm{P}<0.05$ compared with PA group.

Table 2. $\beta$-TC-6 at $48 \mathrm{~h}$ cell proliferation.

\begin{tabular}{|c|c|c|c|c|c|c|c|c|c|c|}
\hline & \multirow{2}{*}{$\frac{\text { Blank group }}{0}$} & \multirow{2}{*}{$\frac{\text { PA group }}{0}$} & \multicolumn{4}{|c|}{$\mathrm{PA}+$ caffeine $(\mu \mathrm{m})$ group } & \multicolumn{4}{|c|}{ Caffeine $(\mu \mathrm{m})$ alone } \\
\hline & & & 1 & 10 & 25 & 100 & 1 & 10 & 25 & 100 \\
\hline OD & $\begin{array}{l}0.259 \pm \\
0.021\end{array}$ & $\begin{array}{l}0.144 \pm \\
0.011^{\dagger}\end{array}$ & $\begin{array}{l}0.161 \pm \\
0.032^{\dagger}\end{array}$ & $\begin{array}{l}0.202 \pm \\
0.051\end{array}$ & $\begin{array}{l}0.230 \pm \\
0.043^{*}\end{array}$ & $\begin{array}{l}0.162 \pm \\
0.040^{\dagger}\end{array}$ & $\begin{array}{l}0.236 \pm \\
0.022\end{array}$ & $\begin{array}{l}0.240 \pm \\
0.041\end{array}$ & $\begin{array}{l}0.269 \pm \\
0.030\end{array}$ & $\begin{array}{l}0.241 \pm \\
0.028\end{array}$ \\
\hline
\end{tabular}

${ }^{\dagger} \mathrm{P}<0.05$ compared with the blank group. $* \mathrm{P}<0.05$ compared with PA group.

Table 3. $\beta-\mathrm{TC}-6$ at $72 \mathrm{~h}$ cell proliferation.

\begin{tabular}{|c|c|c|c|c|c|c|c|c|c|c|}
\hline & \multirow{2}{*}{$\frac{\text { Blank group }}{0}$} & \multirow{2}{*}{$\frac{\text { PA group }}{0}$} & \multicolumn{4}{|c|}{$\mathrm{PA}+$ caffeine $(\mu \mathrm{m})$ group } & \multicolumn{4}{|c|}{ Caffeine $(\mu \mathrm{m})$ alone } \\
\hline & & & 1 & 10 & 25 & 100 & 1 & 10 & 25 & 100 \\
\hline OD & $\begin{array}{l}0.359 \pm \\
0.037\end{array}$ & $\begin{array}{l}0.184 \pm \\
0.026^{\dagger}\end{array}$ & $\begin{array}{l}0.185 \pm \\
0.042^{\dagger}\end{array}$ & $\begin{array}{l}0.274 \pm \\
0.031^{\dagger *}\end{array}$ & $\begin{array}{l}0.280 \pm \\
0.049^{\dagger *}\end{array}$ & $\begin{array}{l}0.175 \pm \\
0.021^{\dagger}\end{array}$ & $\begin{array}{l}0.394 \pm \\
0.033\end{array}$ & $\begin{array}{l}0.420 \pm \\
0.048\end{array}$ & $\begin{array}{l}0.463 \pm \\
0.046\end{array}$ & $\begin{array}{l}0.391 \pm \\
0.024\end{array}$ \\
\hline
\end{tabular}

${ }^{\dagger} \mathrm{P}<0.05$ compared with the blank group. ${ }^{*} \mathrm{P}<0.05$ compared with PA group.

Table 4. $\beta$-TC-6 at $96 \mathrm{~h}$ cell proliferation.

\begin{tabular}{|c|c|c|c|c|c|c|c|c|c|c|}
\hline & \multirow{2}{*}{$\frac{\text { Blank group }}{0}$} & \multirow{2}{*}{$\frac{\text { PA group }}{0}$} & \multicolumn{4}{|c|}{$\mathrm{PA}+$ caffeine $(\mu \mathrm{m})$ group } & \multicolumn{4}{|c|}{ Caffeine $(\mu \mathrm{m})$ alone } \\
\hline & & & 1 & 10 & 25 & 100 & 1 & 10 & 25 & 100 \\
\hline OD & $\begin{array}{l}0.608 \pm \\
0.043\end{array}$ & $\begin{array}{l}0.261 \pm \\
0.033^{\dagger}\end{array}$ & $\begin{array}{l}0.281 \pm \\
0.046^{\dagger}\end{array}$ & $\begin{array}{l}0.452 \pm \\
0.039^{\dagger *}\end{array}$ & $\begin{array}{l}0.463 \pm \\
0.051^{\dagger *}\end{array}$ & $\begin{array}{l}0.300 \pm \\
0.037^{\dagger}\end{array}$ & $\begin{array}{l}0.560 \pm \\
0.053\end{array}$ & $\begin{array}{l}0.625 \pm \\
0.044\end{array}$ & $\begin{array}{l}0.604 \pm \\
0.035\end{array}$ & $\begin{array}{l}0.564 \pm \\
0.046\end{array}$ \\
\hline
\end{tabular}

${ }^{\dagger} \mathrm{P}<0.05$ compared with the blank group. $* \mathrm{P}<0.05$ compared with PA group. 
In a comparison of the effect of different concentrations of caffeine and PA on the apoptosis of $\beta$-TC- 6 cells, apoptosis in the $500 \mu \mathrm{M}$ PA group was clearly increased and cell survival rate decreased compared with that in the blank group. The medium group with caffeine and PA also showed a low cell survival rate and high apoptosis rate compared with the blank group, but survival rates in the 10 and $25 \mu \mathrm{M}$ caffeine groups were higher than that in the PA group, while apoptosis was lower than in the PA group. The survival and apoptosis rates showed no clear differences between the caffeine group and blank group (Table 5 and 6 ).

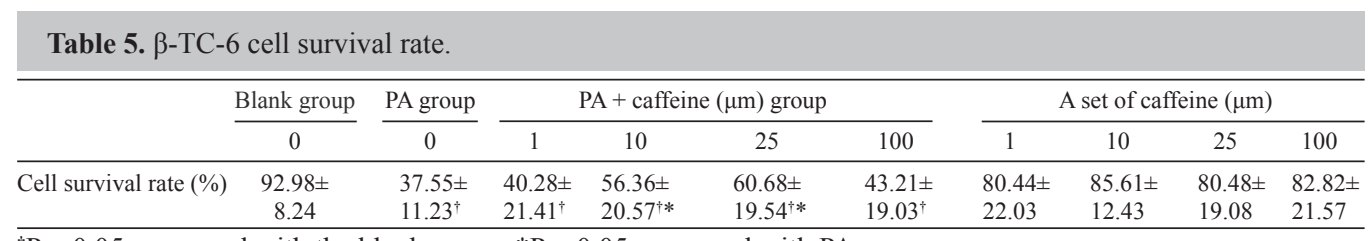

${ }^{\dagger} \mathrm{P}<0.05$ compared with the blank group. ${ }^{*} \mathrm{P}<0.05$ compared with $\mathrm{PA}$ group.

\begin{tabular}{|c|c|c|c|c|c|c|c|c|c|c|}
\hline & \multirow{2}{*}{$\frac{\text { Blank group }}{0}$} & \multirow{2}{*}{$\frac{\text { PA group }}{0}$} & \multicolumn{4}{|c|}{$\mathrm{PA}+$ caffeine $(\mu \mathrm{m})$ group } & \multicolumn{4}{|c|}{ A set of caffeine $(\mu \mathrm{m})$} \\
\hline & & & 1 & 10 & 25 & 100 & 1 & 10 & 25 & 100 \\
\hline Cell apoptosis rate (\%) & $\begin{array}{l}6.68 \pm \\
1.09\end{array}$ & $\begin{array}{l}40.55 \pm \\
20.33^{\dagger}\end{array}$ & $\begin{array}{l}35.88 \pm \\
12.67^{\dagger}\end{array}$ & $\begin{array}{l}19.12 \pm \\
10.56^{\dagger *}\end{array}$ & $\begin{array}{r}20.97 \pm \\
9.75^{\dagger *}\end{array}$ & $\begin{array}{l}38.82 \pm \\
12.43^{\dagger}\end{array}$ & $\begin{array}{l}9.25 \pm \\
6.36\end{array}$ & $\begin{array}{l}8.34 \pm \\
5.48\end{array}$ & $\begin{array}{l}9.86 \pm \\
5.59\end{array}$ & $\begin{array}{c}11.68 \pm \\
6.69\end{array}$ \\
\hline
\end{tabular}

\section{DISCUSSION}

The number of people with diabetes has reached over 90 million worldwide, and most of these cases are type 2 diabetics. Although type 2 diabetics exhibit insulin resistance and impaired islet cell function, the specific pathogenesis of this disease is not well understood. The impairment and damage of $\beta$ cells in type 2 diabetics occurs through $\beta$ cell apoptosis, which has been examined in an increasing number of studies.

The role of lipotoxicity in type 2 diabetic pathogenesis has been given increasing attention. In this study, exposure of $\beta$-TC- 6 cells to high concentrations of free fatty acids for a long or short period of time inhibited cell proliferative activity and increased b apoptosis, which agrees with the results of previous studies (Mason et al., 1999; Wang et al., 2002). The complex pathogenesis of the damage resulting from glucolipotoxicity towards islet $\beta$ cells is not completely understood. Free fatty acid is known to inhibit the cell cycle. With increasing concentrations of free fatty acid in the media, cells in G0 and G1 (early period of DNA synthesis) clearly increase, while cells in S phase (DNA synthesis period) decrease dramatically and cell proliferation is inhibited (Unger and Zhou, 2001). Lipid signals may become stressed through the endoplasmic reticulum, activate the unfolded protein response, and cause cell apoptosis (Karaskov et al., 2006). A previous study reported that free fatty acid may cause $\beta$ cell mitochondrion dysfunction and increase apoptosis by inhibiting the anti-apoptosis B-cell lymphoma 2 gene (Listenberger et al., 2003). Moreover, a relationship may exist between $\beta$ apoptosis caused by free fatty acid, activation of protein kinase $\mathrm{B}$, and increased non-oxidative metabolism (Martinez et al., 2008).

Caffeine is the main component of various liquids consumed on a daily basis, includ- 
ing $35 \mathrm{mg}$ caffeine in $1 \mathrm{~g}$ instant coffee and 30-35 mg in $1 \mathrm{~g}$ tea. In North America, an adult consumes 200-250 mg caffeine each day. In China, caffeine consumption is increasing every year. Caffeine stimulates the central nervous system and has a positive effect on the cardiovascular system. The typical dosage is $16-250 \mathrm{mg} /$ day. Caffeine can increase synthesis of the antagonistic adrenocorticotropic hormone and cortisol by stimulating the pituitary-adrenal axis (Lovallo et al., 1996), suggesting that the diabetes-susceptible population should consume as little caffeine as possible and avoid caffeine addiction. However, because of the popularity of coffee and tea, there will unavoidably be small doses of caffeine consumed. Many recent epidemiological studies suggested that consuming coffee and tea can decrease the incidence of type 2 diabetes. Finland scientists conducted a long-term study of 16,000 Finns and found that consuming coffee every day decreased the incidence of type 2 diabetes. Australian and Japanese scholars also found that drinking coffee every day decreased the rate of type 2 diabetes (Iso et al., 2006; Huxley et al., 2009). Kagami et al. (2008) also found that caffeine can increase the glucose tolerance and insulin content in the pancreas of diabetic rats. These results suggest that caffeine can improve insulin secretion and resistance and prevent type 2 diabetes. However, other studies have shown that caffeine decreased insulin sensitivity and exacerbated insulin resistance (Keijzers et al., 2002; Lane et al., 2004).

Apoptosis of pancreatic $\beta$ cells caused by lipotoxicity is one of the most important pathogenesis indicators of type 2 diabetes. It has been reported that long-term consumption of coffee decreases the risk of type 2 diabetes, but the mechanism is not clear. There have been few reports regarding the impact of caffeine on the survival and function of pancreatic $\beta$ cells. In this study, we examined the effect of the free fatty acid PA and different concentrations of caffeine on pancreatic $\beta$ cells, observed the rate of proliferation and apoptosis of pancreatic $\beta$ cells during cell development, and demonstrated the influence of caffeine on $\beta$ cells in the presence of PA. We found that 10 and $25 \mu \mathrm{M}$ caffeine notably improved the function of PA, resulting in inhibition of $\beta$ cell proliferation and a decrease in apoptosis of $\beta$ cells. Caffeine is a phosphodiesterase inhibitor, and a potential mechanism of caffeine's action may involve increasing cell proliferation that is inhibited by free fatty acid, increasing the cyclic AMP level in the cell to induce the cells to transition from $\mathrm{G}$ phase to $\mathrm{S}$ phase, and improving cell proliferation. Moreover, caffeine has antioxidant effects (Bichler et al., 2007), improves the proliferation of $\beta$ cells inhibited by free fatty acid, and decreases apoptosis caused by free fatty acid by decreasing the oxidization of free fatty acid and formation of free radicals. We found that different concentrations of caffeine had varying effects on pancreatic $\beta$ cells cultured in vitro, did not improve normal proliferation induced by non-free fatty acids, and altered the apoptosis and survival rates, indicating that the improvement role that caffeine plays in cell proliferation and survival may be stronger in individuals showing lipotoxicity.

According to a previous study, serum caffeine concentration in people who drink 2-5 cups of normal coffee per day is approximately $6 \mu \mathrm{g} / \mathrm{mL}(30 \mu \mathrm{M})$ (de Leon et al., 2003); therefore, this study considered a lower caffeine dosage than that found as the routine plasma concentration in a healthy body. We found that caffeine increased pancreatic $\beta$ cell proliferation and decreased apoptosis when free fatty acid was present, indicating that caffeine altered the survival and apoptosis of pancreatic $\beta$ cells. However, caffeine can stimulate the pituitaryadrenal axis and increase secretion of an insulin antagonism hormone. A clinical study found that consuming a large amount of caffeine may decrease glucose tolerance (Greenberg et al., 2010). Although we found that caffeine at a certain concentration may improve $\beta$ cell apoptosis caused by free fatty acid and proliferation activity, larger studies are needed to determine 
whether the host glucose metabolism is influenced by alterations in the survival and apoptosis of $\beta$ cells. The effect of coffee and caffeine on insulin secretion and the role that insulin plays in peripheral tissues should be further examined to clarify the relationship between caffeine and damage to islet $\beta$ cells and glucose metabolism. Additional studies will confirm whether long-term consumption of coffee or tea alters glucose metabolism and prevents type 2 diabetes.

\section{REFERENCES}

Bichler J, Cavin C, Simic T, Chakraborty A, et al. (2007). Coffee consumption protects human lymphocytes against oxidative and 3-amino-1-methyl-5H-pyrido[4,3-b]indole acetate (Trp-P-2) induced DNA-damage: results of an experimental study with human volunteers. Food Chem. Toxicol. 45: 1428-1436.

de Leon J, Diaz FJ, Becoña E, Gurpegui M, et al. (2003). Exploring brief measures of nicotine dependence for epidemiological surveys. Addict Behav. 28: 1481-1486.

Greenberg JA, Owen DR and Geliebter A (2010). Decaffeinated coffee and glucose metabolism in young men. Diabetes Care 33: 278-280.

Huxley R, Lee CM, Barzi F, Timmermeister L, et al. (2009). Coffee, decaffeinated coffee, and tea consumption in relation to incident type 2 diabetes mellitus. Arch. Intern. Med. 169: 2053-2063.

Iso H, Date C, Wakai K, Fukui M, et al. (2006). The relationship between green tea and total caffeine intake and risk for self-reported type 2 diabetes among Japanese adults. Ann. Intern. Med. 144: 554-562.

Kagami K, Morita H, Onda K, Hirano T, et al. (2008). Protective effect of caffeine on streptozotocin-induced beta-cell damage in rats. J. Pharm. Pharmacol. 60: 558-561.

Karaskov E, Scott C, Zhang L, Teodoro T, et al. (2006). Chronic palmitate but not oleate exposure induces endoplasmic reticulum stress, which may contribute to INS-1 pancreatic beta-cell apoptosis. Endocrinology 147: 3398-3407.

Keijzers GB, De Galan BE, Tack CJ and Smits P (2002). Caffeine can decrease insulin sensitivity in humans. Diabetes Care 25: 364-369.

Lane JD, Barkauskas CE, Surwit RS and Feinglos MN (2004). Caffeine impairs glucose metabolism in type 2 diabetes. Diabetes Care 27: 2047-2048.

Listenberger LL, Han X, Lewis SE, Cases S, et al. (2003). Triglyceride accumulation protects against fatty acid induced lipotoxicity. Proc. Natl. Acad. Sci. USA 100: 3077-3082.

Lovallo R, Al'Absi M, Blick K, Whitsett TL, et al. (1996). Stress-like adenocorticotropin responses to caffeine in young healthy men. Pharmacol. Biochem. Behav. 55: 365-369.

Martinez C, Tanabe K, Cras-Méneur C, Abumrad NA, et al. (2008). Inhibition of Foxol protects pancreatic islet beta-cells against fatty and endoplasmic reticulum stress-induced apoptosis. Diabetes 57: 846-859.

Mason M, Goh T, Tchipashvili V, Sandhu H, et al. (1999). Prolonged elevation of plasma free fatty acids desensitizes the insulin secretary response to glucose in vivo in rats. Diabetes 48: 524-530.

Poitout V and Robertson RP (2008). Glucolipotoxicity: fuel excess and beta-cell dysfunction. Endocr. Rev. 29: 351-366.

Unger RH and Zhou YT (2001). Lipotoxicity of beta cells in obesity and other causes of fatty acid spillover. Diabetes 50: 118-121.

Wang Y, Miura Y, Kaneko T, Li J, et al. (2002). Glucose intolerance induced by a high-fat/low-carbohydrate diet in rats effects of nonesterified fatty acids. Endocrine 17: 185-191. 